\title{
Motivation is the Strongest Influence in Choosing Delivery Place
}

\section{Motivasi adalah Faktor yang Paling Kuat Memengaruhi Pemilihan Tempat Persalinan}

\author{
Indria Astuti, Dany Hilmanto, Budi Handono \\ Midwifery Magister study Program, \\ Faculty of Medicine Padjadjaran University \\ Bandung
}

\begin{abstract}
Objective: To analyze the factors that correlated with decision to choose the most appropriate delivery place of mothers' delivery attended by health personnel, in West Bandung District.

Method: This was a case-control study with consecutive sampling method on the mothers who gave birth at two health centers: $\mathrm{Ci}-$ kalong Wetan and Cipongkor, West Bandung District. There were two groups of mothers. First, the case group consisted of 52 mothers at non-healthcare facilities. Second, control group consisted of 52 mothers at healthcare facilities. There were sociodemographic (culture, educational), contextual (income, transportation, distance, availability health facilities) and characteristics of needs (counseling, prenatal care, motivation) factors and dependent variable was decision in choosing the place of delivery. The data was analyzed using chi square test to determine the correlation factors, whereas multiple logistic regression was used to determine the strongest correlating factors.
\end{abstract}

Result: The results showed that there were correlation between various factors with the decision selection of delivery place of the mothers by health care in: cultural factor (OR $=23 ; \mathrm{p}<0.001 ; \mathrm{CI} 95 \%$ : 7.99-66.20), educational factor $(\mathrm{OR}=4.86 ; \mathrm{p}<0.001 ; \mathrm{CI} 95 \%: 1.35-$ 19.09), income factor (OR = 2.36; $\mathrm{p}=0.031$; CI 95\%: 6.51-57.49), transportation factor $(\mathrm{OR}=19.35 ; \mathrm{p}<0.001$; CI 95\%: 6.51 to 57.49 ), distance factor $(\mathrm{OR}=3.19, \mathrm{p}=0.007 ; 95 \% \mathrm{CI}: 1.67-37.69)$, availability health facilities factor $(\mathrm{OR}=7.94, \mathrm{p}=0.007$; CI 95\% 1.67-37.69 and $\mathrm{OR}=3.97$; CI 95\%: 0.40-39.75), counseling factor ( $\mathrm{OR}=23, \mathrm{p}<$ 0.001: CI 95\%: 7.99-66.20), prenatal care factor $(\mathrm{OR}=5.21, \mathrm{p}<$ 0.001; 95\%: 2.24-12.12), motivational factor (OR = 196, $\mathrm{p}<0.001$; CI $95 \%: 41.64-922.48)$. The strongest factor was the motivational factor (OR = 103.33; p < 0.001; CI 95\%: 10.00-1065.72).

Conclusion: This study concluded that there was correlation between sociodemographic, contextual, and characteristics of needs with the decision in choosing place of delivery that attended by health personnel. Motivation was the strongest factor correlated to the mothers' decision to deliver at public health center.

[Indones J Obstet Gynecol 2013; 1-4:173-8]

Keywords: characteristics of demand, contextual, delivery place, socio-demographic

\begin{abstract}
Abstrak
Tujuan: Menganalisis hubungan faktor sosiodemografi, kontekstual, karakteristik kebutuhan dengan keputusan pemilihan tempat persalinan yang ditolong oleh tenaga kesehatan di Kabupaten Bandung Barat.

Metode: Rancangan penelitian adalah kasus kontrol menggunakan teknik concecutive sampling pada ibu bersalin di wilayah Puskesmas Cikalong Wetan dan Cipongkor Kabupaten Bandung Barat. Kelompok kasus adalah 52 ibu bersalin oleh tenaga kesehatan di non faskes dan kelompok kontrol adalah 52 ibu bersalin di faskes. Sebagai variabel adalah faktor sosiodemografi (budaya dan pendidikan), kontekstual (pendapatan, transportasi, jarak dan ketersediaan faskes) dan karakteristik kebutuhan (konseling, pemeriksaan kehamilan dan motivasi) sedangkan variabel tergantung adalah keputusan ibu bersalin memilih tempat persalinan. Analisis data menggunakan uji chi kuadrat dan regresi logistik ganda.
\end{abstract}

Hasil: Penelitian menunjukkan bahwa terdapat hubungan berbagai faktor dengan keputusan pemilihan tempat persalinan pada ibu bersalin yang ditolong oleh tenaga kesehatan, yaitu budaya $(O R=23$; $p<0,001$; IK 95\%:7,99-66,20), pendidikan (OR=4,86; $p<0,001 ;$ IK95\%: 1,35-19,09), pendapatan (OR=2,36; $p=0,031$; IK 95\%: 1,07-5,2), transportasi (OR=19,35; $p<0,001$; IK 95\%: 6,51-57,49), jarak (OR=3,19; $p=0,007$; IK 95\%: 3,19-7,55), ketersediaan faskes (OR=7,94; $p=0,007$; IK 95\%: 1,67-37,69 dan OR=3,97; IK 95\%:0,40-39,75), konseling (OR=23; $p<0,001$; IK 95\%:7,99-66,20), pemeriksaan kehamilan (OR= 5,21; $p<0,001$; IK 95\%: 2,24-12,12), motivasi (OR=196; $p<0,001 ; I K$ 95\%: 41,64-922,48). Faktor yang paling kuat hubungannya adalah motivasi (OR=103,33; $p<0,001$; IK 95\%; 10,00-1065,72).

Kesimpulan: Terdapat hubungan faktor sosiodemografi, kontekstual dan karakteristik kebutuhan dengan keputusan ibu bersalin dalam pemilihan tempat persalinan yang ditolong oleh tenaga kesehatan. Motivasi merupakan faktor paling kuat hubungannya dengan keputusan ibu bersalin di faskes.

[Maj Obstet Ginekol Indones 2013; 1-4: 173-8]

Kata kunci: karakteristik kebutuhan, kontekstual, sosiodemografi, tempat persalinan

Correspondence: Indria Astuti. Midwifery Magister study Program, Faculty of Medicine University of Padjadjaran. Jln Eijkman no 38, Bandung 40132. Telephone: 022-6631624. Email: ind_ast@yahoo.com

\section{INTRODUCTION}

Delivery helped by health workers plays an important role in reducing Mothers Mortality Rate (MMR) and Infant Mortality Rate (IMR). Currently, the MMR and IMR in Indonesia has decreased but it is still considered higher than other developing countries, such as Sri Lanka and Philippines. But, the decline of MMR and IMR in Indonesia was not achieved in the West Bandung area, where the number even tends to increase. . $^{1,2-4}$ 
One important factor to reduce MMR by the reduction of complications that occurred during labor is for the patients to deliver in a healthcare facility. Riskesdas data indicates that most delivery in Indonesia (57.6\%) happened in non-healthcare facilities, while data in West Bandung regency showed a lower percentage (37.29\%) of patients who gave birth in non-healthcare facilities. ${ }^{1,5,6}$

Other data showed that although the majority of Indonesia's population gave birth at home, but the delivery processes were assisted by health workers in most cases (59.8\%). This percentage contrasts with the data in West Bandung area that showed that most home births were attended by nonhealth workers, ( $71.09 \%$ ). ${ }^{4,5}$

The difference in MMR and IMR trend associated with the use of healthcare facilities as the place of birth between National and West Bandung regency area, triggers the interest to analyze the factors associated with the decision to give birth at healthcare facilities or non healthcare care facilities. Up to present time there are no studies linking these factors with the decision of giving birth in healthcare facility or non healthcare care facility.

The purpose of this study is to analyze the correlation between socio-demographic factors (education and culture), contextual (income, transportation, distance and availability of healthcare facilities) and the characteristic needs (counseling, prenatal care, and motivation) with the decisions of choosing the place to give birth and the presence of health workers. Additionally, we would like to assess the strongest factors influencing the mothers' decision to choose the place to give birth.

\section{METHOD}

The study was an observational analytic study with case-control design. The women who chose to give birth in a non healthcare care facilities attended by skilled health workers were assigned to the case group and the mother who gave birth in healthcare facilities were assigned as a control group. This method is used to determine the factors associated with the decision to give birth in healthcare facilities or non-healthcare care facilities.

The subjects of this study were women who give birth in Cikalong Wetan and Cipongkor public health centers, West Bandung area that met the inclusion criteria and were willing to participate in the study after receiving an explanation and filling out the consent form.
Exclusion criteria were the presence of traditional birth attendants (paraji) followed by health workers (midwives) and women with normal delivery who moved from outside the West Bandung area. Criteria for inclusion in the case group and the control group were women who delivered in non- healthcare facilities that had KIA/KMS cards and had normal deliveries, while the exclusion criteria for the case group were women who came to healthcare facilities as a reference case, diagnosed with complications from pregnancy/childbirth and women with normal deliveries who moved from outside the area of West Bandung regency.

This study used a 95\% confidence level and a test of strength (power study) 90\%. Samples were calculated with the difference formula of two proportions. Based on the calculation, this study would require 52 cases sample and 52 control samples. The selection of the sample was using consecutive sampling that started from the research date until the sample met.

Data were collected primarily from subjects who met the study criteria and were willing to be interviewed to be respondents using a questionnaire that had previously been tested and the validity and reliability of secondary data from a cohort of labor and delivery reports midwife. Bivariable data analysis using chi square test to determine the correlation of various independent variables, namely culture, education, income, transportation, distance, availability of healthcare facilities, counseling, pregnancy tests and motivation with the dependent variables, namely the selection of delivery place. We also used multivariable analysis using logistic regression double to determine the most correlated factors.

\section{RESULTS}

The correlation between sociodemographic factors (culture and education), contextual factors (income, transportation, distance, availability healthcare facilities), needs characteristic factors (counseling, prenatal care, and motivation) with the decision to choose place of delivery (non healthcare care facilities or healthcare facilities) attended by health personnel can be seen in Table 1 . 
Table 1. The Correlation between Sociodemographic, Contextual, Characteristics of Demand with the Decision of Choosing Place of Delivery Attended by Health Personnel

\begin{tabular}{|c|c|c|c|c|c|c|}
\hline \multirow{3}{*}{ Variable } & \multicolumn{4}{|c|}{ Group } & \multirow{3}{*}{$\mathbf{p}$} & \multirow{3}{*}{ OR (IK 95\%) } \\
\hline & \multicolumn{2}{|c|}{ Non healthcare facility } & \multicolumn{2}{|c|}{ Health facility } & & \\
\hline & $\mathbf{n}$ & $\%$ & $\mathbf{n}$ & $\%$ & & \\
\hline \multicolumn{7}{|l|}{ Sociodemographic } \\
\hline \multicolumn{7}{|l|}{ Culture } \\
\hline 1. Not Supporting & 39 & 75 & 6 & 11.5 & $<0.001$ & $23(7.99-66.20)$ \\
\hline 2. Supporting & 13 & 25 & 46 & 88.5 & & \\
\hline \multicolumn{7}{|l|}{ Education } \\
\hline 1. Primary & 48 & 92.3 & 37 & 71.2 & 0.005 & $4.86(1.35-19.09)$ \\
\hline 2. Middle and High & 4 & 7.7 & 15 & 28.8 & & \\
\hline \multicolumn{7}{|l|}{ Contextual } \\
\hline \multicolumn{7}{|l|}{ Income } \\
\hline 1. < UMR & 33 & 63.5 & 22 & 42.3 & 0.031 & $2.36(1.07-5.20)$ \\
\hline 2. $\geq$ UMR & 19 & 36.5 & 30 & 57.7 & & \\
\hline \multicolumn{7}{|l|}{ Transportation } \\
\hline 1. Not available & 35 & 67.3 & 5 & 9.6 & $<0.001$ & $19.35(6.51-57.49)$ \\
\hline 2. Available & 17 & 32.7 & 47 & 90.4 & & \\
\hline \multicolumn{7}{|l|}{ Distance } \\
\hline 1. Far & 24 & 46.2 & 11 & 21.2 & 0.007 & $3.19(3.19-7.55)$ \\
\hline 2. Near & 28 & 53.8 & 41 & 78.8 & & \\
\hline \multicolumn{7}{|l|}{ Health facility } \\
\hline 1. Not Available & 12 & 23.1 & 2 & 3.8 & 0.007 & $7.94(1.67-37.69)$ \\
\hline 2. Available not functioning & 3 & 5.8 & 1 & 1.9 & & $3.97(0.40-39.75)$ \\
\hline 3. Available & 37 & 71.2 & 49 & 94.2 & & 1.0 \\
\hline \multicolumn{7}{|l|}{ Characteristics of demand } \\
\hline \multicolumn{7}{|l|}{ Counseling } \\
\hline 1. No & 39 & 75 & 6 & 11.5 & $<0.001$ & $23(7.99-66.20)$ \\
\hline 2. Yes & 13 & 25 & 46 & 88.5 & & \\
\hline \multicolumn{7}{|l|}{ Pregnancy check up } \\
\hline 1. Irregular & 33 & 63.5 & 13 & 25 & $<0.001$ & $5.211(2.24-12.12)$ \\
\hline 2. Regular & 19 & 36.5 & 39 & 75 & & \\
\hline \multicolumn{7}{|l|}{ Motivation } \\
\hline 1. Low & 49 & 94.2 & 4 & 7.7 & $<0.001$ & $196(41.64-922.48)$ \\
\hline 2. High & 3 & 5.8 & 48 & 92.3 & & \\
\hline
\end{tabular}

Note: OR (IK 95\%): Odds ratio and interval confidence 95\%

Table 1 shows that the educational and cultural factors were correlated with the mothers' decision to choose place of delivery (non healthcare care facilities or healthcare facilities). Cultural factors have a greater risk (OR 23) compared to the factor of education (OR 4.86) in the decision to choose the place of delivery in non-healthcare care facilities. Based on contextual factors that the factors of income, transportation, distance and availability of healthcare facilities have correlation with the mothers' decision to choose place of delivery (non healthcare care facilities or healthcare facilities). Transportation factors have the greatest risk to the contextual group (OR 19.35) compared to the factor of income, distance, or availability of maternal healthcare facilities in the decision to choose non healthcare care facilities or healthcare facilities as place of delivery.
Based on characteristic needs we can see that counseling, prenatal care, and motivation factors have correlation with mothers' decision to choose place of delivery (non healthcare care facilities or healthcare facilities). Motivational factors have the greatest risk to the group with characteristics needs (OR 196) compared to counseling, prenatal care or regularity in the maternal decision to choose place of delivery in non healthcare care facilities or healthcare facilities.

\section{Analysis of Multivariable}

At the end of the model below (Table 2) demonstrated the strength of correlation of independent variables with the decision on the selection of the delivery attended by health workers in the non healthcare care facilities or healthcare facilities. 
Table 2. Multiple Logistic Regression Analysis Results Correlations with a Variety Of Independent Variables on Mothers' Decisions by Health Personnel in the Choosing of the Delivery Place (Late Model)

\begin{tabular}{lrccc}
\hline \hline \multicolumn{1}{c}{ Variable } & Coef B & S.E (B) & Sig & OR (IK 95\%) \\
\hline Culture & 2.433 & 1.096 & 0.026 & $11.39(1.33-97.617)$ \\
Motivation & 4.638 & 1.190 & 0.000 & $103.33(10.00-1065.72)$ \\
Transportation & 3.222 & 1.220 & 0.008 & $25.08(2.297-273.80)$ \\
Healthcare facility & 1.233 & 0.843 & 0.144 & $3.43(0.65-17.90)$ \\
Constant & 18.963 & - & - & - \\
\hline \hline
\end{tabular}

Note: the accuration of Model 95.2\%

Table 2 shows that motivational factors showed the strongest correlation (OR 103.33) compared with other factors in the mothers' decision to choose delivery place.

\section{DISCUSSION}

The results of this study showed a correlation between cultural factors with the mothers' decision in the selection of the place of delivery. In the area of research, although most mothers only had elementary education background, but in choosing a place of the delivery, there are cultural influences that tend to be handled by trained personnel (health workers). This can be seen from the high correlation of cultural support in choosing healthcare facilities as a place of birth.

Although most mothers had cultural support from the surrounding environment, especially from her husband and family, but some of the area has rugged terrain and inadequate transportation, causing many mothers to choose to deliver a baby at home (non healthcare care facilities). This is consistent with the theory that local conditions greatly affect the determination to maintain the norms and values that can change the pattern and view of life. ${ }^{7-9}$

The decision to choose healthcare facilities as a place to deliver was mostly made by mothers who had higher education. The results are consistent with the research conducted by Stephenson and Fredrik that indicated that mothers with higher education prefer to give birth in healthcare facilities. ${ }^{10,11}$ The correlation between high levels of mothers education and the selection of healthcare facilities to deliver is in accordance with the theory that the level of education will have an effect in response to stimuli that comes from the outside, thus someone who has a higher education level will provide a rational response than those who are less educated. 7,12

In this study, mothers who have low incomes (incomes less than minimum wage) tend to choose to give birth at home (non healthcare care facilities). This is consistent with the Andersen theory that family income is a contributing factor for someone to use of the healthcare service. ${ }^{13}$ People with higher incomes have more flexibility in the use of revenues for various purposes including health and delivery. ${ }^{10,13}$

Besides, mother's decision in choosing health facilities has to be supported by the availability of transport in the village. The site of this study in West Bandung area has a variety of transportation available. Populations who are living in urban areas have the convenience of public transport provision, although it is not available within 24 hours. On the other hand there are many people living in villages with lack of vehicles facilities and hard road, because the road is small, rugged, and full of rocks. In the villages, ambulance is not available to be used by delivery mothers to go to a healthcare facility, forcing the population to give birth in the non-medical facility (home).

The results of this study indicated that the distance to the delivery place is not really important, but rough terrain and uneven road conditions due to shaped mountains cause mothers to favor the home as a place of delivery.

Distance correlation with the mothers' decision in choosing the place for delivery according to the research conducted by Some, Oomman and Hazemba, suggested that mothers often find barriers in accessing health care for themselves, so that the distance be a reason to give birth at home. $9,14,15$

The results of this study demonstrated the correlation of healthcare facilities availability with the decision in choosing the place of delivery. In West Bandung area there are villages with a healthcare facility that functioning for 24-hours to help the delivery. This is an incentive for women who live in the village to choose healthcare facilities as a place of delivery. On the other hand, there are also villages that do not have delivery healthcare facilities, so the women there prefer to deliver at home.

The results showed there was a correlation between counseling with mothers' decision in choosing the place of delivery. The decision to choose healthcare facilities as a place of delivery was 
mostly made by women who had received counseling. Nevertheless there are still some women who already had counseling but did not choose healthcare facilities, because the counseling delivered by health workers had not been repeated, especially in respondents who were at risk with the previous birth in the home and the women in the area that is difficult to reach. The results are consistent with the research conducted by Stephenson and Kruk saying that the information submitted at the time of pregnancy and childbirth on the benefits of service availability in healthcare facilities cause women to choose the right healthcare facilities. ${ }^{10,16}$

The results of this study showed correlation between the regularity of prenatal check up and the decision in choosing the place of delivery. The selection process for the place of delivery is supported by the regularity of prenatal check up. This could also be seen from the result of a research in which the subjects who had pregnancy check up more than 4 times more commonly delivered in health care facilities compared to the subjects who only had 1 to 3 times check up.

The results are consistent with the research by Stephenson and Fedrik saying that women who during their pregnancy had 4 times or more checkup had the possibility of choosing healthcare facilities as a delivery compared with women who during their pregnancy only had 1 to 3 check ups or never examined their pregnancy. ${ }^{10,11}$

The results of this study showed that there is correlation between motivation and the decision in choosing the place of delivery. The results indicate that with high motivation tend to choose a delivery in healthcare facilities, whereas with low motivation tend to choose a delivery at home (non healthcare care facilities). High Motivation found in women who feel more comfortable, quiet and safe in delivery, while with low motivation usually because they did not feel comfortable and did not have the support of her husband and family.

The results are consistent with the opinion of motivation that states someone would do something to the fullest, taking advantage of the capabilities and skills with eager, if she has the high motivation high. ${ }^{17}$

The results of this study also showed that motivation is the strongest factor linked to the mother's decision in choosing the place of delivery. The re- sults are in line with the theory of needs according to Maslow in Winardi that stated the level of safety need to cover the need for protection from threat, danger, conflict and environment. 17 Delivering mother needs to feel comfortable and safe during the delivery process. It is quite often that they have the pain before the delivery, although childbirth is a natural condition experienced by a mother. ${ }^{18}$

\section{CONCLUSION}

There is a correlation of sociodemographic factors (education and culture), contextual factors (income, distance, transportation, availability of Health facility) and characteristics needs (counseling, prenatal care, and motivation) with decisions of birthplaces selection that attended by medical workers. High motivation is the strongest factor linked with mothers' decision to choose a health facility as a place of delivery.

\section{REFERENCES}

1. Kepmenkes RI, Petunjuk Teknis Jaminan Persalinan. Jakarta; 2011

2. Kepmenkes RI, Buku Profil Kesehatan Indonesia 2009. Jakarta; 2010

3. WHO/UNICEF/UNFPA/World Bank. Trend in mothers and mortality 1999 to 2008. WHO; 2010; 23-6

4. Dinas Kesehatan Kabupaten Bandung Barat, Profil kesehatan Kabupaten Bandung Barat 2010. Bandung; 2010

5. Depkes RI, Laporan Nasional Riset Kesehatan Dasar. Jakarta; 2010

6. Kementerian Kesehatan RI, Pedoman Pelaksanaan Pelayanan Kesehatan Ibu di Fasilitas kesehatan. Jakarta: Dirjen Bina kesehatan Masyarakat; 2010

7. Juliwanto E. Faktor-faktor yang mempengaruhi keputusan memilih penolong persalinan pada ibu hamil di kecamatan Babul Rahman Kab. Aceh Tenggara. USU; 2009

8. Setiadi EM, Hakam KA, Effendi R. Ilmu Sosial dan Budaya Dasar. Jakarta: Kencana; 2009

9. Some TD, Sombie I, Meda N. Women's perceptions of homebirths in two rural medical districts in Burkina Faso: a qualitative study. Reprod Health; 2011

10. Stephenson R, Baschieri A, Clements S, Hennink, Madise N. Contextual Influences on the use of health facilities for Childbirth in Africa. Review. AJPH, 2006; 96( 1): 84-93

11. Fedrik GL, Langi G. Barrirs to delivery care by skilled attendants in Sulawesi Utara, Manado J Public Health Develop, 2009; 7 (3) : 1-9

12. Pomeroy A, Koblinsky M, Alva S. Private Delivery Care in Developing Countries Trends and Determinants. This document was produced for review by the United States Agency for International Development; 2010

13. Andersen R, Newman J. Societal and Individual Determinants of Medical Care Utilization in United States. 2005; 83 (4): $1-24$ 
14. Oomman, Lule, vazirani, Chihabara. Inequelities in health and population. Indonesia. The internasional bank for recontructions and development. Washington DC; 2003; 2021

15. Hazemba AN, Siziyes S, Choice of place for childbirth: prevalence and correlates of utilization of health facilities in Chongwe district, Zambia. Med J Zambia, 2003; 35( 2): 53-6
16. Kruk EM, Paczkowski M, Mbaruku G, Pinho H, Galea S. Women's Preferences For Place of Delivery in Rural Tanzania: A Population-Based Discrete Choice Experiment. AJPH, 2009;99 (9): 1666-72

17. Siagian SP. Teori Motivation dan Aplikasinyes. Jakarta; Rineka Cipta; 2004

18. Sarwono P. Buku Acuan Nasional Pelayanan Kesehatan maternal neonatal.YBP SP Jakarta, 2006; ed I Cet 4 : 100-1 